\title{
Exploration on the Teaching Mode of Ideological and Political Course in MOOC Environment
}

\author{
Minhan Ding ${ }^{1}$, Shixin Liu² \\ ${ }^{1}$ School of Marxism, Wuhan University of Science and Technology, Wuhan, Hubei 430081 \\ ${ }^{2}$ Student Affairs Office (Department), Wuhan University of Science and Technology, Wuhan, Hubei 430081
}

\begin{abstract}
The emergence of MOOC has increased the way for college students to receive curriculum education. Many colleges and universities have established online ideological and political courses (or interdisciplinary politics, ethics, psychology, etc.) on the MOOC platform. Based on the advantages of MOOC and its influence on the teaching mode of ideological and political courses, this paper reasonably applies the existing MOOC resources and combines the actual needs of ideological and political courses to construct the ideological and political course teaching mode under the MOOC environment.
\end{abstract}

\section{Introduction}

Salman Khan initially puts his teaching films on the Internet to help relatives living in the distance, and receives wide acclaim. Later, Khan founds the Khan Institute, a non-profit educational organization, which uses E-learning to attract a large number of students. MOOC is abbreviated from MASSIVE OPEN ONLINE COURSES. It is a large-scale online open course. It is characterized by short videos and accompanying exercises. It presents a series of courses according to the knowledge outlines. After the first year of MOOC development, there has been an upsurge of MOOC construction around the world.[1] The famous open online courses mainly include EDX, Coursera and Udacity. Domestic Tsinghua School, Chinese University MOOC and MOOC network have been launched online. At the same time, Baidu Lecture, Ali Tao Class, Tencent Classroom, 51CTO College, CSDN College, Netease Cloud Classroom, Sina Open, Huawei, ZTE, etc. have established their own teaching platform. There are countless educational entrepreneurial companies in China. In addition, the relatively large online learning environments that are popular abroad are Sakai and Moodle. [2,3]

Many universities have produced a large number of MOOC courses for online teaching on the corresponding MOOC platform, among which there are many MOOC courses on ideological and political theory (hereinafter referred to as ideological and political class)(or its interdisciplinary politics, ethics, psychology, etc.). The adaptation of the worldwide development trend has responded to the implementation of China's "Internet +" development strategy at the level of education and the internationalization, globalization and informatization of
China's higher education reform and development. In April 2015, the Ministry of Education issued the "Advice on Strengthening the Application and Management of Online Open Courses in Colleges and Universities". (hereinafter referred to as the "Advice"). The "Advice" clearly states that "a group of online open courses such as ideological and political theory courses should be constructed in an organized way."[4] This provides a new direction for the integration of Internet and ideological and political teaching.

In such a MOOC environment, combined with the characteristics and requirements of Ideological and political course teaching, MOOC will be integrated into the teaching of Ideological and political course, exploring the full application of MOOC teaching ideas and resources on the basis of Ideological and political teaching. It has become an important subject to establish the mixed teaching mode of ideological and political courses with "students as the subject and teachers as the leading role".

\section{The advantage of MOOC}

\subsection{Perfect teaching design of online courses}

The course teaching design can integrate modules according to the characteristics of the course and complete the course design and upload according to the specific requirements of the platform. The course teaching design of MOOC should conform to the cognitive law of network learners, and a complete teaching system should be established jointly by learners, teachers and the course platform. The specific operations are as follows: the course platform will release the 
specific teaching time of the course on time according to the teaching plan or arrangement, the teaching will be conducted with multimedia video, the classroom and homework will be arranged, and students will communicate and interact in the discussion or assembly area independently. At the same time, instant messaging software and e-mail are used to remind each learner to finish the relevant homework, participate in communication and discussion, and take the final or closing test according to the time node. Teachers can calculate the final grade according to the learners' usual learning situation, homework completion and evaluation results. Such a complete teaching process can help learners to build a systematic knowledge framework.

\subsection{Improved online real-time interactive experience}

Unlike previous online courses, such as distance online courses and other online boutique courses or open courses, MOOC allow anyone to conduct effective online interactive learning based on individual learning time, methods and habits at any time and place of any effective network. For example, in the past, national boutique courses, open online courses and other courses are relatively single, one-way network curriculum resources, can not support the function of interaction between teachers and students, between learners. Of course, MOOC is based on its more humanized course teaching design. In addition, the MOOC platform of Chinese universities has "teacher answering area", "classroom communication area", "comprehensive discussion area" and "student assembly area". Students can carry out more in-depth study through interactive exchanges, doubts, mutual evaluation, experience and so on in this area, so as to enhance the learning objectives in essence.

\subsection{Effective diversified job evaluation mechanism}

The homework adopts a diversified evaluation mechanism. For example, we can set up small test questions in the traditional classroom to help learners to detect their own learning effects in a timely and effective way. We can arrange class and after-class assignments, for example, in a traditional teaching classroom, and then complete and submit the assignments within the deadline for submission; Finally, pass the final examination and get the final certificate. Excellent students can also be selected to help teachers evaluate homework, which can not only share the workload of the lecturers and teaching assistants, but also strengthen the self-reflection of excellent students, so as to cultivate their ability of diversified thinking.

\section{Application of MOOC in ideological and political education}

\subsection{Application of MOOC in ideological and political courses}

In the fall of 2011, MOOC rose rapidly in the United States. Many famous experts consider MOOC as "the biggest innovation of education since the invention of printing".[5] At present, Coursera (course era), edX (online course project) and Udacity (online university) are known as the "three major platforms" of MOOC.[6] The courses on the three platforms mainly focus on science and technology, among which Coursera humanities courses are relatively concentrated and have translated Chinese subtitles for some courses, which is convenient for more domestic students to learn. The humanities courses offered in Coursera include Yale University, Duke University, Princeton University and other world-renowned universities, as well as some Chinese universities such as Taiwan National University, Hong Kong University and Shanghai Jiaotong University.

On the MOOC platform, the interdisciplinary curriculum system of Ideological and political education covers many disciplines, such as politics, ethics, psychology and so on. Moral education is carried out through various explicit or implicit educational contents and forms. In general, although the number of related moral education courses on the MOOC platform is small, it embodies a wide range of characteristics, rich curriculum content and clear value orientation.

MOOC's rich educational resources, new teaching concepts and teaching models have attracted the attention of ideological and political workers. In order to comply with the trend of internationalization of education, improve the quality of teaching, and improve the teaching effect, on March 15, 2014, China's first ideological and political theory class, "Ideological and Moral Cultivation and Legal Basis" was officially opened. It is organized by the Curriculum Sharing Center of Shanghai Universities and under the overall responsibility of professor Gao Guoxi from the Department of Social Science of Fudan University, and is the first mixed large-scale open online political course jointly built by 10 universities including Fudan University, Peking University, Renmin University of China and 23 teachers. At the same time, in Chinese university moocs, that is, in the courses to be taught, Related moral education courses offered by Wuhan University, such as "Chinese Philosophy History", "Aesthetic Psychology", "Introduction to Chinese Culture", "Dialect and Chinese Culture", and "Philosophical Issues" offered by Zhejiang University, effectively make up for the deficiencies of education in moral education courses in Chinese universities at present. More importantly, the "Marxist Philosophical Principles" set up by Wang Xinyi of Wuhan University and the "Outline of Modern and Contemporary Chinese History" set up by Duan Zhiwen of Zhejiang University are officially opened in September. The offering of these two courses is a new attempt and beneficial exploration of the ideological and political course on the MOOC platform, which opens up a new thinking space for the realization of the ideological and political course from explicit knowledge to students' implicit knowledge.

\subsection{MOOC innovative ideological and political} curriculum model 
According to the fluctuation of the teaching resources of online open courses, the demand for changes in teaching forms is triggered, and the innovative teaching model is actively promoted to promote the development of online ideological and political courses through innovative teaching models. The flexibility of online open courses in time and space expands the dimension of ideological and political classes, enriches the form of teaching, and changes the traditional teaching model of "teaching + learning". Instead, the teaching mode of "guidance + learning" is based on the combination of flip, interactive and experiential. "Every major breakthrough in science and technology will have a tremendous impact on education, not only in the use of new technologies and means, but also in the profound changes in educational concepts, content, methods and models."[7] The rise of online open courses has provided a new development trend for the value orientation of traditional ideological and political courses that focuses on teachers' "teaching" and presents the value orientation of students' "learning" and teachers' "guidance" based on students, which enhances students' cognitive experience. After students complete "Internet + network terminal + network registration" through the online open course service platform, students can arrange time and space study independently, and use its "on-demand" characteristics to learn and watch repeatedly. "Students are looking forward to a learning experience that provides a user-friendly, self-service, 24-hour service like a bank and a mall."'[8] Each episode of 5-8 minutes can meet the needs of the audience in a short period of time such as queuing, waiting, taking a car, walking etc. This kind of teaching that combines online and offline, reality and virtual society, and learning and life is more likely to enter student life and enter the students' hearts.

\section{Mixed teaching model of ideological and political courses based on MOOC}

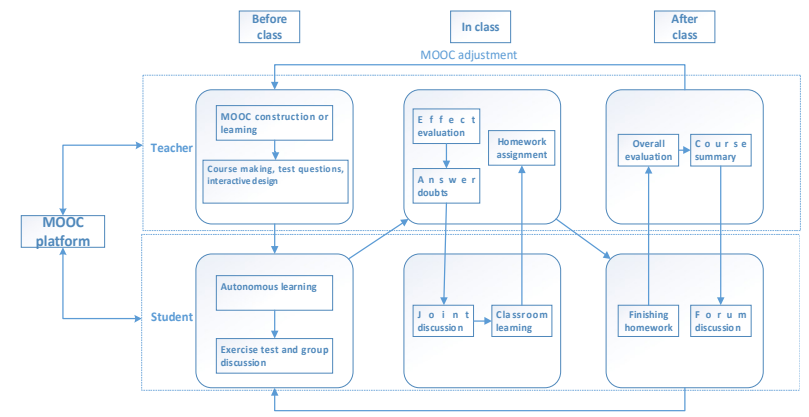

Figure 1. Mixed teaching mode of ideological and political courses based on MOOC.

\subsection{Before class stage}

\subsubsection{Teaching design}

Teaching design is very important for teachers to finish teaching activities. Teachers should analyze students' learning situation and grasp students' knowledge reserve. On this premise, students' characteristics should be fully explored, their organizational forms should be appealing, the selection of resources should be diversified, and the control of rhythm should be flexible. The core of the online open course is the micro-course video resource and teacher's information technology application ability is the guarantee for making micro-courses. First, teachers should be able to design exquisite PPT courseware, use video software, learn simple picture processing, animation production, and edit video in the later stage; The overall teaching design idea is example teaching, explaining profound theories in simple language, video animation, intuitive and easy to understand. Using various fragmented resources to explain knowledge points, the abstract, boring, boring knowledge through pictures, animation, video and other resources to demonstrate, so that teachers can achieve the effect of easy to teach, so that learners can achieve the effect of easy to learn.

\subsubsection{Course outline}

Due to the different background of basic knowledge, most of the science and engineering students do not know the basic knowledge of the four ideological and political courses. This online course designs a well-organized teaching outline, which gives a brief introduction to the teacher's situation and the information related to the course. Therefore, learners can have a certain understanding of the basic principles, historical context and current political information before learning. Compared with offline learning model, teachers often adopt the teaching outline provided by the school. However, there are obvious differences in the progress and methods of online learning, so we should choose the teaching activities which are consistent with the learners' progress, and change with the change of learning content to achieve more targeted teaching methods.

\subsection{In class stage}

4.2.1 Classroom teaching. In the classroom, teachers need to explain in depth the logical structure, key difficulties, historical background and other issues between the course knowledge, so that students form a basic understanding of the curriculum. At the same time, teachers can use the videos, pictures, music, etc. related to the teaching knowledge to stimulate students' interest in learning and motivate students to learn.

4.2.2 Video viewing. In order to deeply understand and master the classroom teaching knowledge, after the class is over, a certain number of online videos will be arranged on the MOOC platform every week. Each video is kept at around 10 minutes, and the overall time is planned according to the course requirements. Some small tests can be embedded in the video as a part of the student's self-examination, and then asked to feedback the existing questions in the MOOC forum area.

4.2.3 Interaction. This online course combines the advantages of the traditional teaching model with the interactive nature of learners' online learning. Many teaching videos have designed knowledge explanations closely related to the teaching content, and cooperate with 
various multimedia display means and practice tests to stimulate the subjective interest of the learners, thus helping to improve the quality of learning. The teaching of each chapter knowledge takes into account its relevance before and after, and requires learners to learn according to the progress of the teaching content. For example, only when we have a clear understanding of the relationship between matter and consciousness can we continue to learn the laws of understanding and development of things, otherwise, problems will arise in our understanding. The above three steps complete a cycle of learning from classroom teaching to MOOC network teaching, and then to classroom teaching. In this process, the teacher's guiding role has been fully exerted, and the enthusiasm of students' independent learning has been fully mobilized. Teachers' response to each student's questions is not only their concern for the knowledge world, but also their concern for the spiritual world. It enables students to acquire new knowledge while training their independent thinking ability and enhancing their sense of social responsibility. It really realizes the transformation of Ideological and political lessons from the textbook system to the teaching system.

\subsection{After class stage}

4.3.1 Assignment completion. The ideological and political course adopts thematic teaching and teaches a topic every week according to the teaching content. In order to test the learning effect and find out the problems in teaching, a certain amount of homework can be arranged every week in the MOOC homework area. The content can come from the training questions of the textbook, and the evaluation can be made according to the theory and the hot social issues. For example, in teaching the connotation of the "Chinese Dream" and the way to realize the problem, students can be asked to talk about their Chinese dream, and how to achieve these dreams, through practice to constantly improve students' understanding of the problem, and problem solving ability.

4.3.2 After class discussion. Although many similar online courses have designed learning forum model, but the design methods are different. In the MOOC network course, learning forum is designed into the learning content of the chapter. The function of forum is mainly to answer questions. On this network platform, learners can enter the discussion area to exchange ideas after completing the learning of each chapter. The discussion area is tightly structured and the content is presented in a modular manner. MOOC forum area can be divided into course content area, course assignment area, study group area, comprehensive discussion area, technical consultation area, etc. It is convenient for students to ask questions and answer questions. Students can also post posts to discuss teaching content. These posts will be organized by a dedicated teacher, and the main issues to the lecturer to answer. Therefore, in the forum, teachers can always pay attention to each student's questions and ideological changes, and can promptly answer, encourage or correct deviations.
4.3.3 Course evaluation. The evaluation of mixed teaching mode mainly adopts the combination of network evaluation and traditional evaluation. On the MOOC platform, teachers can check students' feedback information at any time, such as the completion of homework, the number of discussions, the quality of speech and so on. The problem of forum discussion area should generally be an open question and no unified answer is required. Students can use what they have learned freely, so that teachers can judge their progress according to the students' discussion status and incorporate it into their daily performance.

\section{Conclusion}

This paper briefly describes the ideological and political teaching concept based on MOOC, and explores the mixed teaching mode by combining the features of ideological and political theory; The course teaching is divided into three stages, and the MOOC platform is used for course design, teaching and discussion and evaluation. With teachers as the study leader and students as the study subject, we can make use of the complementary advantages of online and offline teaching, and support the interactive and adaptive evaluation to meet the personalized learning needs. This paper provides a new teaching method for ideological and political education. It is a beneficial innovation attempt of ideological and political education model.

\section{References}

1. Yang Zhuyu, Zheng Qi. Initial Exploration of Online Education Mode Like MOOC [J] Science-Technology \& Publication, 2014 (2): 9-12.

2. Sakai Project: Collaboration and Learning for Educators by Educators [EB/OL]. http://www.sakaiproject.org, 2014-09-13.

3. Open-source Community-based Tools for Learning [EB/OL]. http://moodle.org, 2014-07-17.

4. People's Republic of China Ministry of Education Portal Website."Opinions of the Ministry of Education on Strengthening the Application of Online Open Courses in Colleges and Universities to Management" [2015] No. 3, April 28, 2015. http://www.moe.edu.cn/publicfiles/business/htmlfiles /moe/s7056/201504/186490.Html.

5. Liu Aihua. The Specific Application of Group Psychological Counseling in College Mental Health Education [J]. Journal of Hunan Mass Media Vocational and Technical College, 2013, (5): 111-112.

6. Ai Silin. MOOC: Opportunities and Challenges of Ideological and Political Theory Courses in Colleges and Universities [J], Beijing Education (Moral Education), 2014(10): 6 .

7. COOPERS. MOOCs: Disrupting the University or Business as Usual? [EB/OL]. [2013-11-20]. http://arena.Org.au/moocs-disrupting-the-universityor-business-as -usual/. 